\title{
Amorphous nanosilica induce endocytosis- dependent ROS generation and DNA damage in human keratinocytes
}

\author{
Hiromi Nabeshi, ${ }^{1,2}$, Tomoaki Yoshikawa ${ }^{1,2^{*}}$, Keigo Matsuyama ${ }^{1,2}$, Yasutaro Nakazato ${ }^{1,2}$, Saeko Tochigi ${ }^{1,2}$, \\ Sayuri Kondoh 1,2, Toshiro Hirai ${ }^{1,2}$, Takanori Akase ${ }^{1,2}$, Kazuya Nagano ${ }^{2}$, Yasuhiro Abe ${ }^{2}$, Yasuo Yoshioka ${ }^{2,3}$, \\ Haruhiko Kamada ${ }^{2,3}$, Norio Itoh', Shin-ichi Tsunoda ${ }^{1,2,3}$, Yasuo Tsutsumi ${ }^{1,2,3^{*}}$
}

\begin{abstract}
Background: Clarifying the physicochemical properties of nanomaterials is crucial for hazard assessment and the safe application of these substances. With this in mind, we analyzed the relationship between particle size and the in vitro effect of amorphous nanosilica (nSP). Specifically, we evaluated the relationship between particle size of nSP and the in vitro biological effects using human keratinocyte cells (HaCaT).

Results: Our results indicate that exposure to nSP of $70 \mathrm{~nm}$ diameter (nSP70) induced an elevated level of reactive oxygen species (ROS), leading to DNA damage. A markedly reduced response was observed using submicron-sized silica particles of 300 and $1000 \mathrm{~nm}$ diameter. In addition, cytochalasin D-treatment reduced nSP70-mediated ROS generation and DNA damage, suggesting that endocytosis is involved in nSP70-mediated cellular effects.

Conclusions: Thus, particle size affects amorphous silica-induced ROS generation and DNA damage of HaCaT cells. We believe clarification of the endocytosis pathway of nSP will provide useful information for hazard assessment as well as the design of safer forms of nSPs.
\end{abstract}

\section{Background}

With recent developments in nanotechnology, various kinds of nanomaterials have been designed and produced throughout the world. Nanomaterials have been widely used in consumer and industrial applications, such as medicine, cosmetics and foods, because they exhibit unique physicochemical properties and innovative functions [1]. For example, materials such as amorphous silica nanoparticles (nSPs) and titanium dioxide $\left(\mathrm{TiO}_{2}\right)$ are colorless and reflect ultraviolet light more efficiently than micro-sized particles. Consequently, these substances are already used as functional ingredients in many cosmetics such as foundation creams and sunscreens.

However, concerns over the potentially harmful effects of nanomaterials have been raised precisely because they possess novel properties that are different from those of

\footnotetext{
* Correspondence: tomoaki@phs.osaka-u.ac.jp; ytsutsumi@phs.osaka-u.ac.jp ${ }^{1}$ Graduate School of Pharmaceutical Sciences, Osaka University, 1-6 Yamadaoka, Suita, Osaka 565-0871, Japan

Full list of author information is available at the end of the article
}

microsized materials. Increasing numbers of studies show that many types of nanomaterials, such as carbon nanotubes, fullerenes, quantum dots, zinc oxide and $\mathrm{TiO}_{2}$, have a harmful effect on cells and rodents [2-14]. For example, previous studies reported that various nanoparticles induced toxicological effects mainly in lung, liver, spleen and kidney tissues [3,10,15-19]. In vivo toxicity studies in Sprague Dawley rats showed that inhaled silver nanoparticles elicited chronic inflammation in the lungs [20]. After intravenous injection with silica nanoparticles in BALB/c mice, $70 \mathrm{~nm}$ particles induced liver injury at $30 \mathrm{mg} / \mathrm{kg}$, while $300 \mathrm{~nm}$ or $1000 \mathrm{~nm}$ had no effect [21]. Recent evidence indicates that the small size and high surface area of nanomaterials may cause unpredictable genotoxic properties [22]. For example, induction of DNA damage by gold-, silver-, cobalt-, $\mathrm{TiO}_{2}$-nanoparticles has been reported. The results from various studies suggest that these nanomaterials may cause DNA damage by an indirect pathway through promoting oxidative stress and inflammatory responses via dysfunction of

C 2011 Nabeshi et al; licensee BioMed Central Ltd. This is an Open Access article distributed under the terms of the Creative Commons 
mitochondria or inflammasomes. Central to the study of nanotoxicology is genotoxicity, the study of genetic aberrations following exposure to nanomaterials, because it is known that an increased genetic instability is associated with the development of cancer.

A sufficient understanding of the relationship between the physicochemical characteristics of nanomaterials governing their cytotoxicity (i.e. genotoxicity) and the identification of factors that influence their associated hazards are essential for the development of safer nanomaterials [22-25]. Since the linkage analysis is the sole methods for developing safe nanomaterials, many researchers have conducted extensive efforts [26-30]. In this context, the aim of our study was to investigate the relationship between particle size and in vitro hazard of amorphous nanosilica (nSP), especially focusing on DNA damage, using human keratinocyte cells.

\section{Results and Discussion}

We first analyzed the physicochemical properties of the commercially available silica particles of 70, 300 and $1000 \mathrm{~nm}$ in diameter (nSP70, nSP300 and mSP1000, respectively). Close examination of the silica particles of different particle sizes (nSP70, nSP300, mSP1000) by scanning electron microscopy (SEM) revealed that all the particles used in this study were spherical and the primary particle sizes were approximately uniform (Figure 1A-C). The size distribution spectrum of each set of silica particles in a neutral solvent showed a single peak. Moreover, the average particle size corresponded almost precisely to the anticipated size for each sample (Figure 1D and 1E). These results suggest that the silica particles used in this study remained as stable welldispersed particles in solution.

Cosmetic products containing nSP, such as those used in skincare treatments, have been on the market
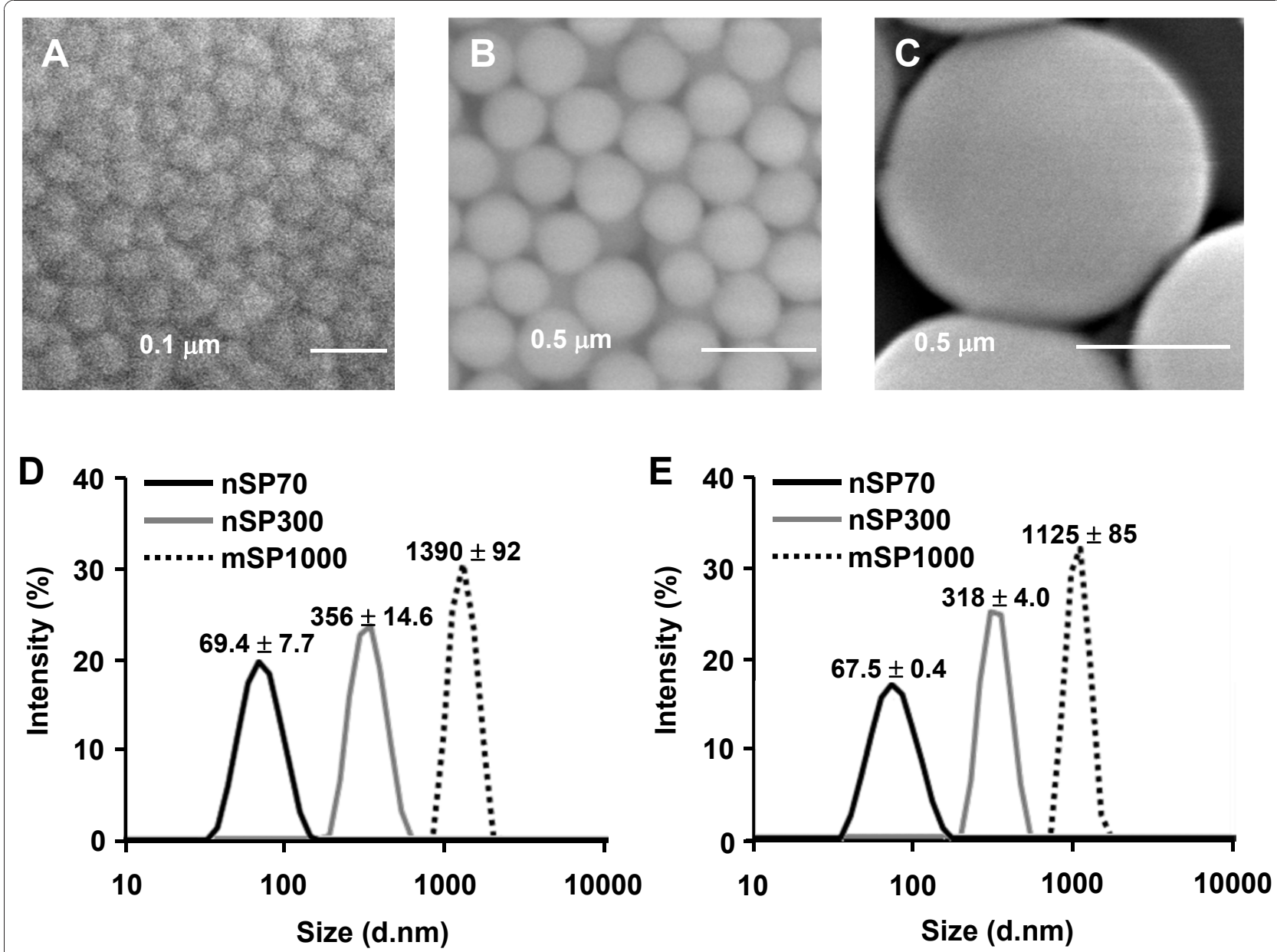

Figure 1 Scanning electron microscopy (SEM) analysis and spectrum of size distribution of amorphous silica particles. (A-C) SEM photomicrographs of silica particles used in this study: nSP70 (A), nSP300 (B) and mSP1000 (C). Scale bars: 0.1 mm (A) and 0.5 mm (B and C). ( $\mathbf{D}$ and E) Size distribution of nSP70 (black), nSP300 (gray) and mSP1000 (dashed line) in water (D) or PBS (E) were measured by a dynamic light scattering method. 
for a considerable period of time. Adult human skin has an average surface area of $1.95 \mathrm{~m}^{2}$, weighs $3.18 \mathrm{~kg}$ and comprises over 300 million cells. The skin is the largest organ in the human body, which provides protection against heat, cold, electromagnetic radiation and chemical damage. Indeed, skin cells are likely to have the highest frequency of exposure to nSPs. Hence, a safety evaluation of nSPs using dermal cells is essential. Based on this consideration, using the $\mathrm{HaCaT}$ human keratinocyte cell line as a model system, we studied the effects of various sized silica particles on cell function. Specifically, we used $\mathrm{HaCaT}$ cells to perform the $\mathrm{LDH}$ release assay to assess membrane damage induced by silica particles. We found that membrane damage was not observed in nSP300- and mSP1000-treated $\mathrm{HaCaT}$ cells. By contrast, LDH release increased after exposure of the cells to nSP70 in a dose-dependent manner (Figure 2). This observation suggested that membrane damage in keratinocytes increased significantly when the particle size was less than $100 \mathrm{~nm}$. The decrease of particle size changes the physicochemical properties of the silica particles, such as surface area and the number of functional groups per particle weight, which are both increased [31-34]. In addition, subsequent experiments were performed at a nontoxic dose (less than $300 \mu \mathrm{g} / \mathrm{ml}$ ) in order to exclude the toxic effects of nSP70.

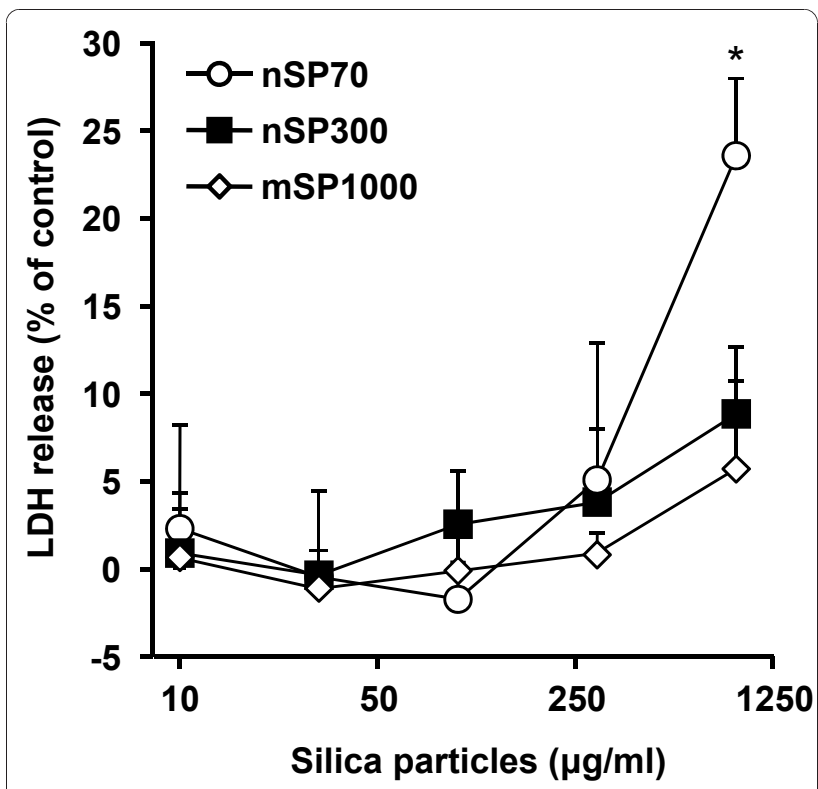

Figure 2 Effect of silica particles on membrane damage. Cellular membrane damage in $\mathrm{HaCaT}$ cells after incubation with nSP70 (circles), nSP300 (squares) and mSP1000 (diamonds) for $24 \mathrm{~h}$ was evaluated by the LDH release assay. The percentage cellular membrane damage was calculated relative to the negative (medium) controls. Data are presented as means $\pm \mathrm{SD}(\mathrm{n}=3){ }^{*} P<$ 0.01 vs same dose of nSP300 and mSP1000.
Some reports have indicated that intracellular generation of reactive oxygen species (ROS) is induced by $\mathrm{nSP}$ [35-37]. Furthermore, it has recently been reported that crystalline silica induces intracellular ROS generation via NADPH oxidase activation following uptake by endocytosis $[38,39]$. Based on these reports, ROS generation and DNA damage are an obvious means of assessing the hazard posed by nSP. Firstly, total intracellular ROS generation was measured in silica particle-treated $\mathrm{HaCaT}$ cells using 2'7'-dichlorodihydorofluorescein diacetate (DCFH-DA). Silica particles of all sizes were found to induce intracellular ROS generation in a dose-dependent fashion (Figure 3A). However, ROS generation by $\mathrm{nSP70}$ treatment was significantly greater compared with nSP300 and mSP1000 treatment at the same particle concentration. Additionally, we confirmed that hydroxyl radicals, one of the most highly reactive ROS, were generated in $\mathrm{HaCaT}$ cells treated with silica particles, in particular with nSP70 (Figure 3B). Even in the $10 \mu \mathrm{g} / \mathrm{ml}$-treated group, hydroxyl radical-generation effects of nSP70-treatment were 1.4 times higher than that of nSP300 and mSP1000treated groups. These results suggested that silica particleinduced intracellular ROS generation was significantly increased by decreasing the particle size to less than 100 nm. ROS are defined as either "primary" or "secondary". Primary ROS (e.g. superoxide, $\mathrm{O}_{2}^{-}$) can be generated through metabolic processes or through the activation of oxygen, which results in the formation of a reactive nucleophilic molecule of oxygen i.e., superoxide anion. These reactive species may interact with other molecules, such as redox active transition metals (e.g. iron) or enzymes, resulting in the production of "secondary" ROS (e.g. $\left.{ }^{\circ} \mathrm{OH}\right)$, which are primary mediators of DNA damage. Consequently, we analyzed the formation of 7'8'-dihydro8-oxodeoxyguanosine (8-OH-dG) as an indicator of ROSinduced DNA damage. When $\mathrm{HaCaT}$ cells were treated with various concentrations of silica particles for $3 \mathrm{~h}, 8$ $\mathrm{OH}-\mathrm{dG}$ levels in nSP300- and mSP1000-treated cells remained constant regardless of silica particle dose and were equal to the levels found in untreated cells (Figure $3 \mathrm{C})$. By contrast, 8-OH-dG levels increased upon exposure of the cells to nSP70 in a dose-dependent manner. After treatment with nSP70 at $90 \mu \mathrm{g} / \mathrm{ml}$ the level of $8-\mathrm{OH}-\mathrm{dG}$ increased significantly compared with non-treated cells.

8-OH-dG is known as a major index of oxidative DNA damage related to mutagenesis, carcinogenesis and the aging process $[40,41]$. These reports, together with our results, suggest the possibility that nSP70 may be carcinogenic. Moreover, nSP-induced ROS may induce genotoxicity via DNA strand breaks, oxidative DNA damage and mutation. Indeed, DNA damage was detected in nSP70-treated $\mathrm{HaCaT}$ cells. In addition, nSP70-mediated DNA damage was inhibited by pretreatment with the ROS scavenger, $\mathrm{N}$-acetylcystein 

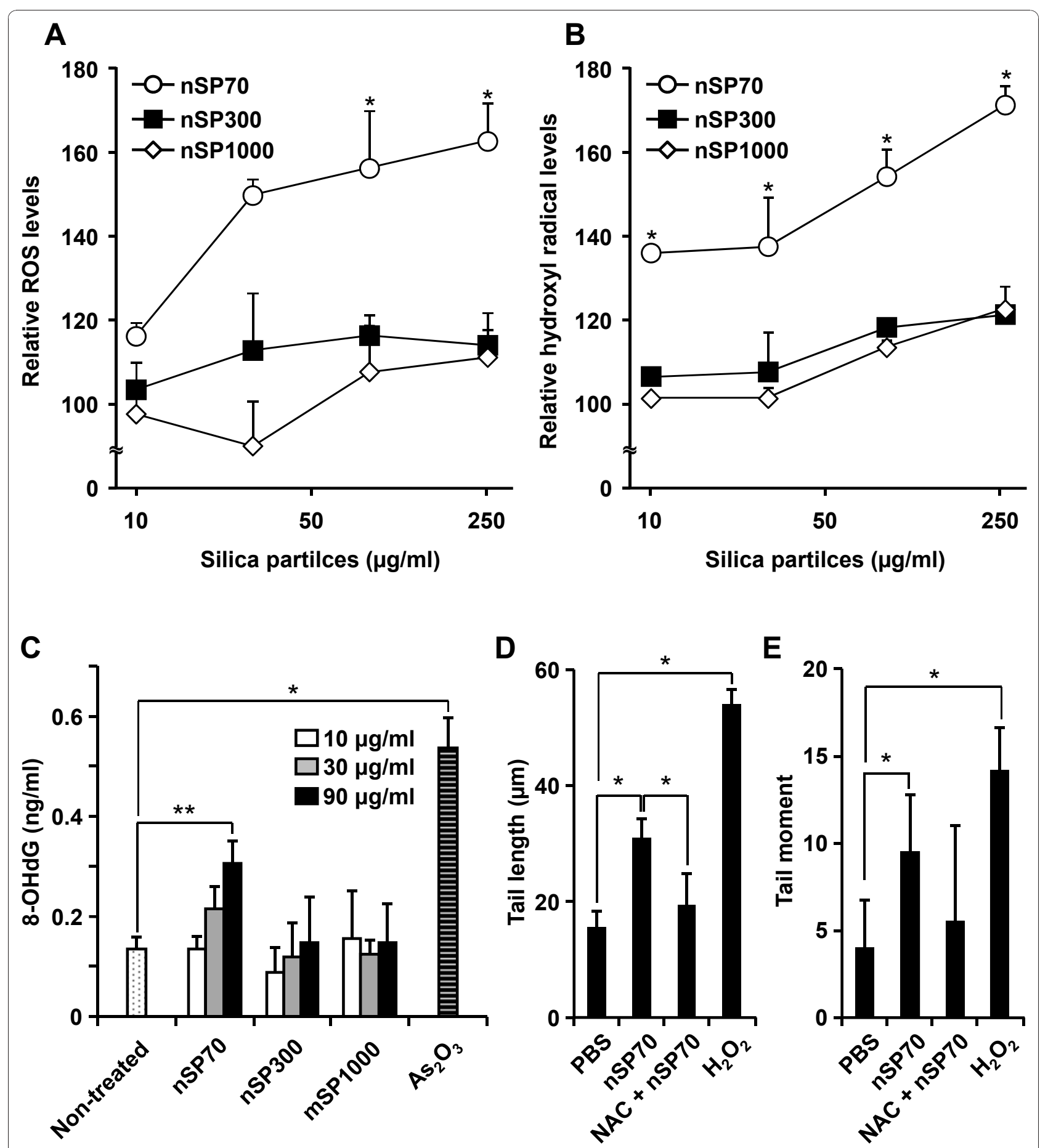

Figure 3 Detection of oxidative stress induced by silica particle treatment in HaCaT cells. Detection of total ROS and hydroxyl radical induced by silica particle treatment in HaCaT cells. HaCaT cells were incubated with various concentrations of nSP70 (circles), nSP300 (squares), and mSP1000 (diamonds) for $3 \mathrm{~h}$. (A) Total ROS induced by treatment with silica particles were expressed as relative fluorescence units in the DCFH assay. ${ }^{*} P<0.01$ vs same dose of nSP300 and mSP1000. (B) Hydroxyl radical was measured by hydroxyphenyl fluorescein (HPF) assay. Data shown are means \pm SD $(n=3) . * P<0.01$ vs same dose of $n S P 300$ and $\mathrm{mSP} 1000$. (C) Detection of 8-OH-dG induced by silica particle treatment in $\mathrm{HaCaT}$ cells. $\mathrm{HaCaT}$ cells were incubated with 10, 30 or $90 \mathrm{mg} / \mathrm{ml} \mathrm{nSP70}$, nSP300, or mSP1000, and $\mathrm{As}_{2} \mathrm{O}_{3}$ (positive control) for 3 h. Data shown are means $\pm S D(n=3) .{ }^{*} P<0.01$, ${ }^{* *} P<0.05$. ( $\mathbf{D}$ and $\left.\mathbf{E}\right)$ Effects of ROS inhibitor on DNA strand breaks induced by silica particle treatment in $\mathrm{HaCaT}$ cells. HaCaT cells were pretreated with $2 \mathrm{mM} \mathrm{N}$-acetylcystein (NAC) for $30 \mathrm{~min}$ (NAC + nSP70) or nSP70 alone, prior to incubation with 90 $\mathrm{mg} / \mathrm{ml} \mathrm{nSP70} \mathrm{for} 3 \mathrm{~h}$. As a positive control, HaCaT cells were treated with $0.2 \mathrm{mM} \mathrm{H}_{2} \mathrm{O}_{2}$ for $3 \mathrm{~h}$. (D) Column height shows the tail length. (E) Column height shows the tail moment. Data shown are means \pm SD of at least 16 cells per sample. Results shown are representative of more than three independent experiments. ${ }^{*} P<0.01$. 
(NAC) (Figure 3D and 3E). From the results of the present study, we suggest that ROS play an important role in cellular responses such as nSP-induced DNA damage. However, the reason why ROS generation varies with particle size has not yet been clarified.

Fine or ultrafine particulate matter (PM), such as diesel exhaust particles or crystalline silica, often induces ROS generation that contributes to the induction of DNA damage or apoptosis. Although the mechanisms underlying the PM-induced oxidative stress response remains unclear, strong evidence supports PM phagocytosis as a stimulus for increased oxidative stress via NADPH oxidase activation $[38,42,43]$. In addition, Walee Chamulitrat et al. reported that $\mathrm{HaCaT}$ cells constitutively express Nox components Rac1, p40phox, and p67phox proteins [44]. In HaCaT skin keratinocyte cells, stimuli such as epidermal growth factor, $\mathrm{Ca}^{2+}$-ionophore A23187, lysophosphatidic acid are capable of producing ROS [45-47]. Thus, one potential candidate for the nSP70-mediated DNA damage is ROS, which is produced by NADPH oxidase upon nSP70 phagocytosis. In order to assess the relationship between the uptake pathway and ROS generation, we measured the production of ROS induced by nSP70 in the presence or absence of a specific inhibitor of endocytosis. After treatment with cytochalasin D, an inhibitor of actin polymerization [48], ROS generation induced by nSP70 was measured by DCFH-DA assay. Results indicated that ROS generation induced by $\mathrm{nSP70}$ was inhibited by pretreatment with cytochalasin $\mathrm{D}$ in a dose-dependent manner (Figure 4). Furthermore, nSP70-induced DNA damage was also significantly reduced by pretreatment with cytochalasin D (Figure 5A and 5B). These findings suggest that the silica particles entered the cells mainly through actin-mediated endocytosis, such as the macropinocytosis pathway, thereby inducing ROS generation and DNA damage. It is well-known that NADPH oxidase, which exists in the cytosol, cellular membrane and subcellular compartment membranes, becomes activated and generates ROS after ingestion of microorganisms into the phagosome and/or endosome [49-51]. Moreover, it is reported that $\mathrm{TiO}_{2}$ particles induce IL-1ß production by NADPH oxidase-mediated ROS generation in the human macrophage cell line [52]. Likewise, NADPH oxidase exists in the cytosol and membranes of non-phagocyte cells, including $\mathrm{HaCaT}$ cells [44]. Additionally, it had been reported that inflammasomes are activated by actin-mediated endocytosis of crystalline silica, which lead to NADPH oxidase activation and ROS generation $[38,39,53]$. Consequently, in order to determine the role of NADPH oxidase in silica particleinduced ROS generation, the effects of pretreatment with the NADPH oxidase inhibitor, apocynin, a wellknown NOX inhibitor $[49,54]$, were investigated. As

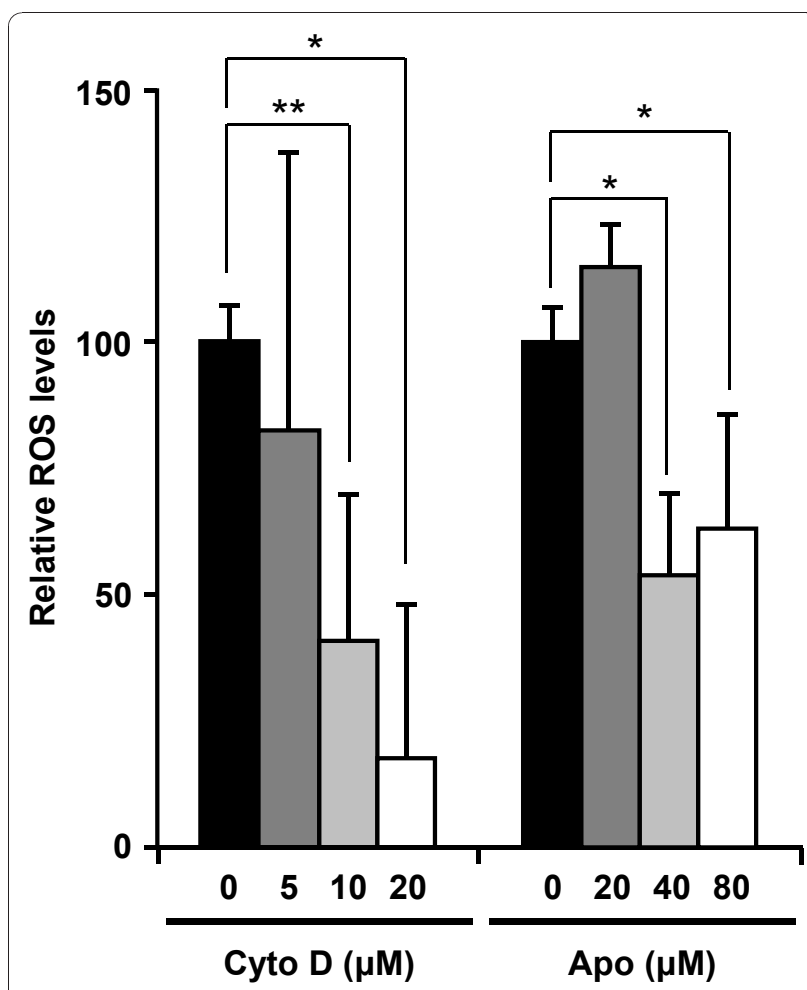

Figure 4 Effects of endocytosis and NADPH oxidase inhibitor on generation of ROS induced by silica particle treatment. $\mathrm{HaCaT}$ cells were pretreated with cytochalasin D or apocynin for $30 \mathrm{~min}$ prior to incubation with $270 \mathrm{mg} / \mathrm{ml} \mathrm{nSP} 70$ for $3 \mathrm{~h}$. ROS induced by silica particle treatment were expressed as relative fluorescence units, which means that ROS intensity of each silica particle alone and non-treatment is 100 and 0 respectively, in the DCFH assay. Data shown are means \pm SD $(n=3) .{ }^{*} P<0.01,{ }^{* *} P<0.05$.

expected, nSP70-induced ROS generation was inhibited in the presence of apocynin (Figure 4). In contrast, DNA damage induced by nSP70 was not inhibited by pretreatment with apocynin (Figure 5C and 5D). Taken together, these results suggest that nSP70-mediated DNA damage was induced by ROS generated by an unknown mechanism, and not via NADPH oxidase. Nox1 activation may initiate large bursts of ROS that can mediate the killing of pathogens, such as $H$. pylori [55]. Thus, NOX1 activation has been implicated in the cutaneous innate immunity to bacterial infections of the skin. A more detailed evaluation of the mechanism that underlies nSP70-mediated NOX activation is essential. Nonetheless, based on our results and the work of others, we speculate that nSP70s are treated almost like pathogens by $\mathrm{HaCaT}$ cells.

A number of mechanisms underlie the ability of nanoparticles to cause DNA damage. As mentioned above, a key mechanism that is often described is the ability of particles to cause the production of ROS $[32,56]$. One possible mechanism of particle-mediated DNA damage 


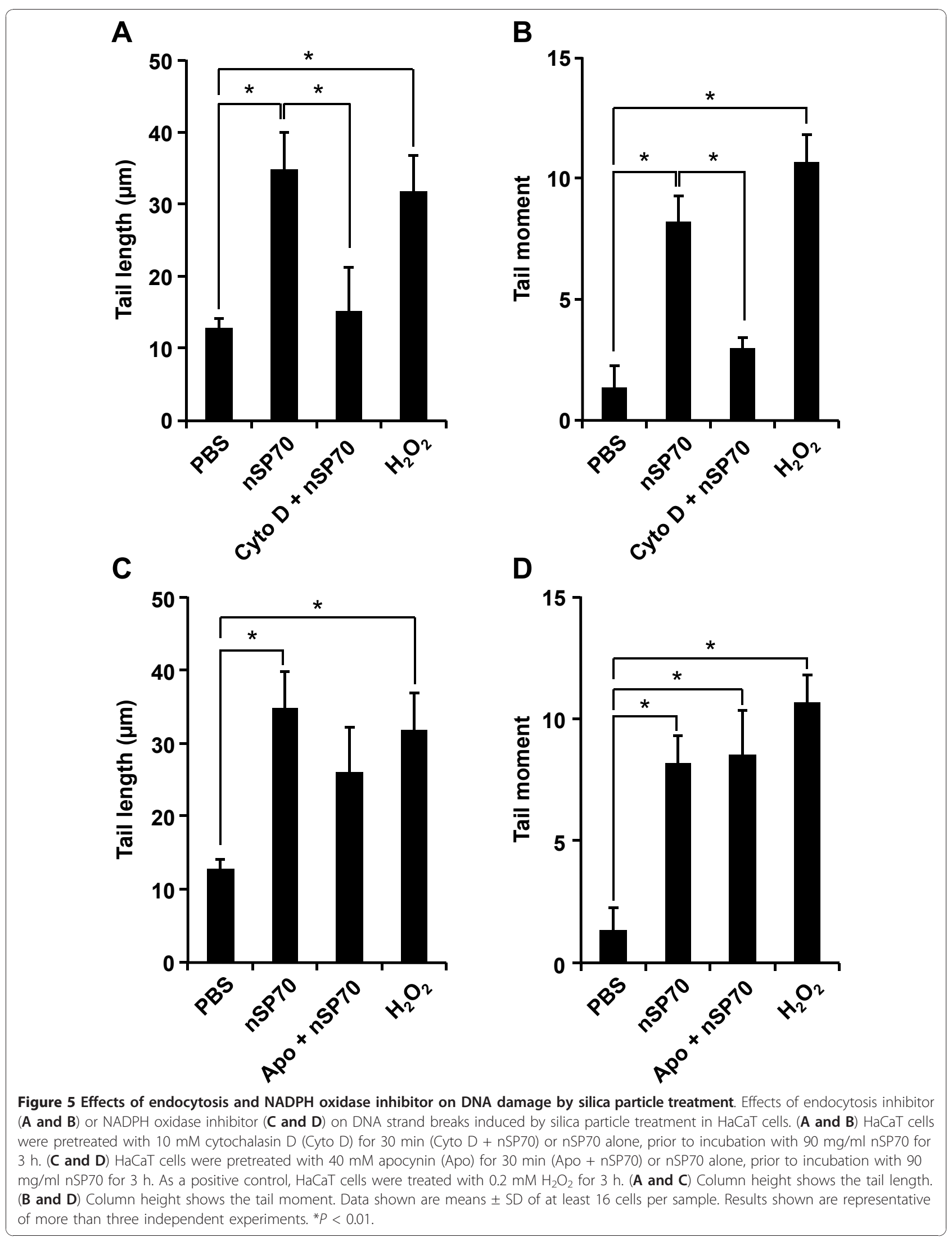


is the ability of particles to stimulate target cells to produce oxidants/genotoxic compounds e.g., by affecting mitochondrial electron transport, activation of NADPH oxidase, or inducing cytochrome P450 enzymes. Our results show that nSP70-mediated DNA damage of $\mathrm{HaCaT}$ cells occurred via a mechanism that did not involve NADPH oxidase. Alternatively, transition metal ions (such as cadmium, chromium, cobalt, copper, iron, nickel, titanium and zinc) released from certain nanoparticles have the potential to cause the conversion of cellular oxygen metabolic products such as $\mathrm{H}_{2} \mathrm{O}_{2}$ and superoxide anions to hydroxyl radicals, which is one of the primary DNA damaging species. Well-known examples of the consequences of metal ion-contamination in relation to nanotoxicity have been described for carbon nanotubes. Indeed, iron contaminants in CNT have been shown to result in a substantial loss of glutathione and increased lipid peroxidation in alveolar macrophages, indicators of oxidative stress [57]. However, our data suggests that the nSPs used in this study, nSP70, nSP300 and mSP1000, were not contaminated with metal ions (data not shown). Thus, it is highly unlikely that metal ion contamination is involved in nSP70induced DNA damage. Another hypothesis is that the size of nSPs is related to its oxidative stress. As particle size decreases, the particle unit of mass and overall surface area increases. This larger surface area enhances catalytic activity. Indeed, it has been widely reported that increased surface area of these particles increases reactivity because surface atoms have a tendency to possess high energy bonds. In order to gain stabilization, these surface bonds will readily react with other molecules [58]. The specific surface area was calculated by means of the following equation; $s=6 / d \rho$ (where $s$, specific surface area $\left(\mathrm{m}^{2} / \mathrm{g}\right) ; \rho$, density $(\mathrm{g} / \mathrm{cc}) ; \mathrm{d}$, diameter $(\mu \mathrm{m})$ ). The specific surface area of nSP70, nSP300 and mSP1000 calculated using this equation was 43,10 and $3 \mathrm{~m}^{2} / \mathrm{g}$, respectively. When specific area is considered, rather than particle concentration, the membrane damage activity of nSP70 and nSP300-treated cells shows almost the same level of LDH release per unit surface area (data not shown). In terms of ROS generation and DNA oxidation, nSP70 is more potent than nSP300. These results suggest that nSP70, which possesses a larger specific surface area compared to the counterpart micron-sized silica particles, has a much greater chance of interaction with biomolecules. Consequently, nSP70 causes direct cellular damage and promotion of oxidative stress. In addition to these hypotheses, nanoparticles may gain direct access to DNA via nuclear transport. However, this mechanism seems very unlikely given that the nuclear pore complex is known to be $8-30 \mathrm{~nm}$ in diameter, depending on cell type [59]. Nonetheless, some studies have reported that nanoparticles can penetrate the nuclear membrane, such as silica nanoparticles (40-70 nm) [60]. Detailed analysis of the mechanism of DNA damage induced by nanoparticles is currently underway. This information will be a critical determinant in the design of safer nSPs and will provide valuable information for hazard assessment of nSPs.

Here, we report the effects induced by well-dispersed amorphous silica particles (nSPs) on human keratinocyte $(\mathrm{HaCaT})$ cells. In addition to our own work, other studies have shown that well-dispersed nSPs induce cytotoxicity, including LDH release, in a dose-dependent and size-dependent manner using a macrophage cell line $[61,62]$. On the other hands, Lin et al. reported that nSPs mediated cytotoxicity/DNA damage against A549 cells were not correlated with particle size [36]. Further, Barnes et al. reported that nSP induce no genotoxicity in fibroblast 3T3-L1 cells [63]. From the viewpoint of nSP-mediated toxicity, there is no consistency in these four reports including our findings. As mentioned above, there are a number of examples in the literature of conflicting results regarding nSPs. It has becoming increasingly evident that the physicochemical properties of nanomaterials, such as the size, shape, surface charge, fabricating method, etc, play a central role in governing their cellular uptake and subsequent physiologic consequences. Furthermore, experimental conditions, such as cell type and incubation time, are critical for the nanotoxicologic studies. Hence, given the inconsistencies it is difficult to draw the same conclusions. However, our results using well-dispersed nSPs indicated that nSPs were more cytotoxic and genotoxic against the human keratinocyte cell line $\mathrm{HaCaT}$.

\section{Conclusions}

In this study, we show that nSP induce certain cellular responses, such as ROS generation and DNA damage. By contrast, their bulk-sized counterparts display a much reduced response. These different responses might be partly due to different mechanisms, such as intracellular uptake and ROS generation. We speculated that receptor-mediated uptake was involved in these phenomena and set out to identify the physicochemical properties that affect receptor endocytosis. We believe a detailed analysis of nSP-internalization will be invaluable for both hazard assessment and the design of safe nSPs.

\section{Materials and methods \\ Silica particles}

Suspensions of fluorescent (red-F)-labeled amorphous silica particles (Micromod Partikeltechnologie $\mathrm{GmbH}$ ) $(25 \mathrm{mg} / \mathrm{ml}$ and $50 \mathrm{mg} / \mathrm{ml}$ ) were used in this study; particle size diameters were 70,300 and $1000 \mathrm{~nm}$ (designated as nSP70, nSP300 and mSP1000, 
respectively). Silica particle suspensions were stored in the dark at room temperature. The suspensions were sonicated for $5 \mathrm{~min}$ and then vortexed for $1 \mathrm{~min}$ immediately prior to use.

\section{Cell Culture}

The HaCaT human keratinocyte cell line was kindly provided by Dr. Inui [64], Osaka University. HaCaT cells were cultured in Dulbecco's modified Eagle's medium (D-MEM) supplemented with $10 \%$ heat-inactivated fetal bovine serum and $0.2 \mathrm{mM}$ L-glutamine. The cells were grown in a humidified incubator at $37^{\circ} \mathrm{C}(95 \%$ room air, $5 \% \mathrm{CO}_{2}$ ).

\section{Physicochemical examinations of silica particles}

Silica particle suspensions were diluted to $0.25 \mathrm{mg} / \mathrm{ml}$ (nSP70), $0.5 \mathrm{mg} / \mathrm{ml}$ (nSP300 and mSP1000) with water or PBS, respectively and the average particle sizes were then measured using the Zetasizer Nano-ZS (Malvern Instruments Ltd). The mean size and the size distribution of silica particles were measured by a dynamic light scattering method. The size and shape of silica particles were determined using scanning electron microscopy (SEM). Each silica particle suspension was dropped on the sample stage and dried. The dried silica particles were then observed by SEM.

\section{LDH release assay}

Lactate dehydrogenase (LDH) is released from $\mathrm{HaCaT}$ cells exposed to nSP70, nSP300 or mSP1000. The LDH activity of the supernatant of the culture medium was determined using a commercial LDH cytotoxicity test (WAKO, Japan) according to the manufacturer's instructions. In brief, $5 \times 10^{3}$ cells were seeded into each well of a 96-well plate. After $24 \mathrm{~h}$ incubation, cells were treated with nSP70, nSP300, mSP1000 or $0.2 \%$ Tween 20 (positive control). After a further $24 \mathrm{~h}$ incubation period, $50 \mu \mathrm{l}$ of medium overlying cells was used for LDH analysis. Absorption of light at $560 \mathrm{~nm}$ was measured using a spectrophotometer.

\section{Detection of Reactive Oxygen Species (ROS)}

The generation of total intracellular ROS was measured by monitoring the increasing fluorescence of 2'7'dichlorofluorescein (DCF). The cell-permeant 2'7'dichlorodihydorofluorescein diacetate (DCFH-DA; Sigma, St. Louis, MO) enters the cell where intracellular esterases cleave off the diacetate group. The resulting DCFH is retained in the cytoplasm and oxidized to DCF by ROS. Hydroxyl radical was measured by monitoring the increasing fluorescence of hydroxyphenyl fluorescein (HPF; SEKISUI MEDICAL Co., Ltd., Japan). $3 \times 10^{4}$ $\mathrm{HaCaT}$ cells were seeded into each well of a 96-well plate. After $24 \mathrm{~h}$ incubation, cells were treated with
nSP70, nSP100, nSP300, mSP1000 or $2 \mathrm{mM} \mathrm{H}_{2} \mathrm{O}_{2}$ (positive control). Cells were then washed once with phenol red-free medium, and incubated in $100 \mu \mathrm{l}$ working solution of DCFH-DA or HPF $(10 \mu \mathrm{M})$ at $37^{\circ} \mathrm{C}$ for $30 \mathrm{~min}$. Using the fluorescence reader (ARVO MX; Perkin Elmer, Waltham, MA), the fluorescence of DCF or HPF was monitored at the excitation and emission wavelengths of $485 \mathrm{~nm}$ and $530 \mathrm{~nm}$ or $490 \mathrm{~nm}$ and $515 \mathrm{~nm}$, respectively.

\section{8-Hydroxy-2-deoxyguanosine (8-OH-dG) measurement}

$\mathrm{HaCaT}$ cells were seeded on a $100 \mathrm{~mm}$ dish. After $24 \mathrm{~h}$, cells were treated with various concentrations of nSP70, nSP300, mSP1000, $0.2 \mathrm{mM} \mathrm{H}_{2} \mathrm{O}_{2}$ (positive control) or PBS (negative control). After $3 \mathrm{~h}$, cellular DNA was isolated using DNeasy tissue kit (QIAGEN, Germany). Ten $\mu \mathrm{g}$ of DNA was converted to single stranded DNA by incubation with $180 \mathrm{U}$ Exonuclease III (Takara Biotech., Japan) at $37^{\circ} \mathrm{C}$ for $1 \mathrm{~h}$. The DNA was heated at $95^{\circ} \mathrm{C}$ for $5 \mathrm{~min}$, rapidly chilled on ice, and digested to nucleosides by incubation with $0.6 \mathrm{U}$ nuclease P1 (Takara) at $37^{\circ} \mathrm{C}$ for $1 \mathrm{~h}$ followed by treatment with $0.6 \mathrm{U}$ E. coli alkaline phosphatase (Takara) for a further $1 \mathrm{~h}$. The reaction mixture was centrifuged $(6000 \times \mathrm{g}$ for $1 \mathrm{~min})$ and the supernatant used for the 8-OHdG assay. The amount of 8-OHdG was measured according to the protocol of the competitive ELISA kit (8-OHdG check; Japan Institute for the Control of Aging, Japan).

Effects of inhibitor of ROS, endocytosis or NADPH oxidase on DNA strand breaks induced by silica particles

$3 \times 10^{4} \mathrm{HaCaT}$ cells were pretreated with $2 \mathrm{mM} \mathrm{N}$ acetylcystein (NAC, ROS scavenger), $10 \mathrm{mM}$ cytochalasin D (endocytosis inhibitor) or $40 \mathrm{mM}$ apocynin (NADPH oxidase inhibitor) for $30 \mathrm{~min}$ prior to incubation with $90 \mathrm{mg} / \mathrm{ml}$ of $\mathrm{nSP70}$ for $3 \mathrm{~h}$. As a positive control, $\mathrm{HaCaT}$ cells were treated with $0.2 \mathrm{mM} \mathrm{H}_{2} \mathrm{O}_{2}$ for 3 h. DNA strand breaks were detected by alkaline comet assay according to the Comet Assay Kit (Trevigen, Gaithersburg, MD). The samples were processed according to the protocol provided in the kit. Twenty-five cells on each slide, randomly selected by fluorescence microscopy, were then analyzed using the Comet Analyzer (Youworks Corporation, Japan).

\section{Effects of inhibitor of endocytosis, NADPH oxidase or endosomal acidification on generation of ROS induced by silica particles}

$\mathrm{HaCaT}$ cells were pretreated with various concentration of cytochalasin D (Merck Ltd., Germany) for $30 \mathrm{~min}$ prior to incubation with $270 \mathrm{mg} / \mathrm{ml} \mathrm{nSP70} \mathrm{for} 3 \mathrm{~h}$. ROS induced by treatment with silica particles were expressed as relative fluorescence units in the DCFHDA assay as described above. 


\section{Statistical analysis}

Statistical comparisons between groups were performed by one-way ANOVA and a Bonferroni post hoc test. The level of significance was set at $P<0.05$.

\section{Acknowledgements}

This study was supported in part by Grants-in-Aid for Scientific Research from the Ministry of Education, Culture, Sports, Science and Technology of Japan, and from the Japan Society for the Promotion of Science (JSPS). This study was also supported in part by Health Labour Sciences Research Grants from the Ministry of Health, Labor and Welfare of Japan; by Health Sciences Research Grants for Research on Publicly Essential Drugs and Medical Devices from the Japan Health Sciences Foundation; by a Global Environment Research Fund from Minister of the Environment; and by a the Knowledge Cluster Initiative; and by Food Safety Commission; and by The Nagai Foundation Tokyo; and by The Cosmetology Research Foundation; and by The Smoking Research Foundation.

\section{Author details}

'Graduate School of Pharmaceutical Sciences, Osaka University, 1-6 Yamadaoka, Suita, Osaka 565-0871, Japan. ${ }^{2}$ Laboratory of Biopharamceutical Research (Pharmaceutical Proteomics), National Institute of Biomedical Innovation, 7-6-8, Saito-Asagi, Ibaraki, Osaka, 567-0085, Japan. ${ }^{3}$ The Center for Advanced Medical Engineering and Informatics, Osaka University, 1-6, Yamadaoka, Suita, Osaka, 565-0871, Japan.

\section{Authors' contributions}

HN and TY designed the study. HN, KM, YN, STo, SK, TH and TA performed experiments. $\mathrm{HN}$ and TY collected and analysed data. HN and TY wrote the manuscript. KN, YA, YY, HK, NI and STs gave technical support and conceptual advice. YT supervised the all of projects. All authors discussed the results and commented on the manuscript.

\section{Competing interests}

The authors declare that they have no competing interests.

Received: 13 September 2010 Accepted: 15 January 2011 Published: 15 January 2011

\section{References}

1. Salata O: Applications of nanoparticles in biology and medicine. J Nanobiotechnology 2004, 2:3.

2. Aiso S, Yamazaki K, Umeda Y, Asakura M, Takaya M, Toya T, Koda S, Nagano K, Arito H, Fukushima S: Pulmonary Toxicity of Intratracheally Instilled Multiwall Carbon Nanotubes in Male Fischer 344 Rats. Ind Health 2010.

3. Chen J, Dong X, Zhao J, Tang G: In vivo acute toxicity of titanium dioxide nanoparticles to mice after intraperitioneal injection. J App/ Toxicol 2009, 29:330-337.

4. Geys J, Nemmar A, Verbeken E, Smolders E, Ratoi M, Hoylaerts MF, Nemery B, Hoet PH: Acute toxicity and prothrombotic effects of quantum dots: impact of surface charge. Environ Health Perspect 2008, 116:1607-1613.

5. Heng BC, Zhao X, Xiong S, Ng KW, Boey FY, Loo JS: Toxicity of zinc oxide ( $\mathrm{ZnO})$ nanoparticles on human bronchial epithelial cells (BEAS-2B) is accentuated by oxidative stress. Food Chem Toxicol 2010, 48:1762-1766.

6. Kocbek P, Teskac K, Kreft ME, Kristl J: Toxicological Aspects of Long-Term Treatment of Keratinocytes with $\mathrm{ZnO}$ and $\mathrm{TiO}(2)$ Nanoparticles. Small 2010, 6:1908-1917.

7. Liu S, Xu L, Zhang T, Ren G, Yang Z: Oxidative stress and apoptosis induced by nanosized titanium dioxide in PC12 cells. Toxicology 2010, 267:172-177.

8. Moos PJ, Chung K, Woessner D, Honeggar M, Cutler NS, Veranth JM: ZnO particulate matter requires cell contact for toxicity in human colon cancer cells. Chem Res Toxicol 2010, 23:733-739.

9. Murray AR, Kisin E, Leonard SS, Young SH, Kommineni C, Kagan VE, Castranova V, Shvedova AA: Oxidative stress and inflammatory response in dermal toxicity of single-walled carbon nanotubes. Toxicology 2009, 257:161-171.
10. Park EJ, Kim H, Kim Y, Yi J, Choi K, Park K: Carbon fullerenes (C60s) can induce inflammatory responses in the lung of mice. Toxicol Appl Pharmacol 2010, 244:226-233.

11. Poland CA, Duffin R, Kinloch I, Maynard A, Wallace WA, Seaton A, Stone V, Brown S, Macnee W, Donaldson K: Carbon nanotubes introduced into the abdominal cavity of mice show asbestos-like pathogenicity in a pilot study. Nat Nanotechnol 2008, 3:423-428.

12. Shin JA, Lee EJ, Seo SM, Kim HS, Kang JL, Park EM: Nanosized titanium dioxide enhanced inflammatory responses in the septic brain of mouse. Neuroscience 2010, 165:445-454.

13. Takagi A, Hirose A, Nishimura T, Fukumori N, Ogata A, Ohashi N, Kitajima S, Kanno J: Induction of mesothelioma in p53+/- mouse by intraperitoneal application of multi-wall carbon nanotube. J Toxicol Sci 2008, 33:105-116.

14. Yamashita K, Yoshioka Y, Higashisaka K, Morishita Y, Yoshida T, Fujimura M, Kayamuro H, Nabeshi H, Yamashita T, Nagano K, et al: Carbon nanotubes elicit DNA damage and inflammatory response relative to their size and shape. Inflammation 2010, 33:276-280.

15. Chen Z, Meng H, Xing G, Chen C, Zhao Y, Jia G, Wang T, Yuan H, Ye C, Zhao $F$, et al: Acute toxicological effects of copper nanoparticles in vivo. Toxicol Lett 2006, 163:109-120.

16. Duan Y, Liu J, Ma L, Li N, Liu H, Wang J, Zheng L, Liu C, Wang X, Zhao X, et al: Toxicological characteristics of nanoparticulate anatase titanium dioxide in mice. Biomaterials 2010, 31:894-899.

17. Li JJ, Muralikrishnan S, Ng CT, Yung LY, Bay BH: Nanoparticle-induced pulmonary toxicity. Exp Biol Med (Maywood) 2010, 235:1025-1033.

18. Li N, Duan Y, Hong M, Zheng L, Fei M, Zhao X, Wang J, Cui Y, Liu H, Cai J, et al: Spleen injury and apoptotic pathway in mice caused by titanium dioxide nanoparticules. Toxicol Lett 2010, 195:161-168.

19. Liang G, Yin L, Zhang J, Liu R, Zhang T, Ye B, Pu Y: Effects of subchronic exposure to multi-walled carbon nanotubes on mice. J Toxicol Environ Health A 2010, 73:463-470

20. Sung JH, Ji JH, Yoon JU, Kim DS, Song MY, Jeong J, Han BS, Han JH, Chung YH, Kim J, et al: Lung function changes in Sprague-Dawley rats after prolonged inhalation exposure to silver nanoparticles. Inhal Toxicol 2008, 20:567-574.

21. Nishimori H, Kondoh M, Isoda K, Tsunoda S, Tsutsumi Y, Yagi K: Silica nanoparticles as hepatotoxicants. Eur J Pharm Biopharm 2009, 72:496-501.

22. Aillon KL, Xie Y, El-Gendy N, Berkland CJ, Forrest ML: Effects of nanomaterial physicochemical properties on in vivo toxicity. Adv Drug Deliv Rev 2009, 61:457-466

23. Hoshino A, Fujioka K, Oku T, Suga M, Sasaki FY, Ohta T, Yasuhara M, Suzuki K, Yamamoto K: Physicochemical Properties and Cellular Toxicity of Nanocrystal Quantum Dots Depend on Their Surface Modification. Nano Letters 2004, 4:2163-2169.

24. Morishige T, Yoshioka Y, Inakura H, Tanabe A, Yao X, Narimatsu S, Monobe $Y$, Imazawa T, Tsunoda S, Tsutsumi $Y$, et al: The effect of surface modification of amorphous silica particles on NLRP3 inflammasome mediated IL-1 beta production, ROS production and endosomal rupture. Biomaterials 2010, 31:6833-6842

25. Sohaebuddin SK, Thevenot PT, Baker D, Eaton JW, Tang L: Nanomaterial cytotoxicity is composition, size, and cell type dependent. Part Fibre Toxicol 2010, 7:22.

26. Fourches D, Pu D, Tassa C, Weissleder R, Shaw SY, Mumper RJ, Tropsha A: Quantitative nanostructure-activity relationship modeling. ACS Nano 2010, 4:5703-5712.

27. Puzyn T, Leszczynska D, Leszczynski J: Toward the development of "nanoQSARs": advances and challenges. Small 2009, 5:2494-2509.

28. Shaw SY, Westly EC, Pittet MJ, Subramanian A, Schreiber SL, Weissleder R: Perturbational profiling of nanomaterial biologic activity. Proc Natl Acad Sci USA 2008, 105:7387-7392.

29. Tropsha A, Golbraikh A: Predictive QSAR modeling workflow, model applicability domains, and virtual screening. Curr Pharm Des 2007, 13:3494-3504.

30. Weissleder R, Kelly K, Sun EY, Shtatland T, Josephson L: Cell-specific targeting of nanoparticles by multivalent attachment of small molecules. Nat Biotechnol 2005, 23:1418-1423.

31. Borm P, Klaessig FC, Landry TD, Moudgil B, Pauluhn J, Thomas K, Trottier R, Wood S: Research strategies for safety evaluation of nanomaterials, part V: role of dissolution in biological fate and effects of nanoscale particles. Toxicol Sci 2006, 90:23-32. 
32. Nel A, Xia T, Madler L, Li N: Toxic potential of materials at the nanolevel. Science 2006, 311:622-627.

33. Rahman IA, Vejayakumaran P, Sipaut SC, Ismail J, Chee KC: Size-dependent physicochemical and optical properties of silica nanoparticles. Materials Chemistry and Physics 2009, 114:328-332.

34. Xia T, Kovochich M, Brant J, Hotze M, Sempf J, Oberley T, Sioutas C, Yeh Iار Wiesner MR, Nel AE: Comparison of the abilities of ambient and manufactured nanoparticles to induce cellular toxicity according to an oxidative stress paradigm. Nano Lett 2006, 6:1794-1807.

35. Eom HJ, Choi J: Oxidative stress of silica nanoparticles in human bronchial epithelial cell, Beas-2B. Toxicol In Vitro 2009, 23:1326-1332

36. Lin $W$, Huang $Y W$, Zhou XD, Ma Y: In vitro toxicity of silica nanoparticles in human lung cancer cells. Toxicol Appl Pharmacol 2006, 217:252-259.

37. Wang F, Gao F, Lan M, Yuan H, Huang Y, Liu J: Oxidative stress contributes to silica nanoparticle-induced cytotoxicity in human embryonic kidney cells. Toxicol In Vitro 2009, 23:808-815.

38. Dostert C, Petrilli V, Van Bruggen R, Steele C, Mossman BT, Tschopp J: Innate immune activation through Nalp3 inflammasome sensing of asbestos and silica. Science 2008, 320:674-677.

39. Hornung V, Bauernfeind F, Halle A, Samstad EO, Kono H, Rock KL, Fitzgerald KA, Latz E: Silica crystals and aluminum salts activate the NALP3 inflammasome through phagosomal destabilization. Nat Immunol 2008, 9:847-856.

40. Ames BN: Dietary carcinogens and anticarcinogens. Oxygen radicals and degenerative diseases. Science 1983, 221:1256-1264.

41. Harman D: The aging process. Proc Natl Acad Sci USA 1981, 78:7124-7128.

42. Li Z, Hyseni X, Carter JD, Soukup JM, Dailey LA, Huang YC: Pollutant particles enhanced $\mathrm{H} 2 \mathrm{O} 2$ production from $\mathrm{NAD}(\mathrm{P}) \mathrm{H}$ oxidase and mitochondria in human pulmonary artery endothelial cells. Am J Physiol Cell Physiol 2006, 291:C357-365.

43. Wang T, Chiang ET, Moreno-Vinasco L, Lang GD, Pendyala S, Samet JM, Geyh AS, Breysse PN, Chillrud SN, Natarajan V, Garcia JG: Particulate matter disrupts human lung endothelial barrier integrity via ROS- and p38 MAPK-dependent pathways. Am J Respir Cell Mol Biol 2010, 42:442-449.

44. Chamulitrat W, Stremmel W, Kawahara T, Rokutan K, Fujii H, Wingler K, Schmidt HH, Schmidt R: A constitutive NADPH oxidase-like system containing gp91 phox homologs in human keratinocytes. J Invest Dermatol 2004, 122:1000-1009.

45. Goldman R, Moshonov S, Zor U: Generation of reactive oxygen species in a human keratinocyte cell line: role of calcium. Arch Biochem Biophys 1998, 350:10-18.

46. Goldman R, Moshonov S, Zor U: Calcium-dependent PAF-stimulated generation of reactive oxygen species in a human keratinocyte cell line. Biochim Biophys Acta 1999, 1438:349-358.

47. Sekharam M, Cunnick JM, Wu J: Involvement of lipoxygenase in lysophosphatidic acid-stimulated hydrogen peroxide release in human HaCaT keratinocytes. Biochem J 2000, 346(Pt 3):751-758.

48. Sampath P, Pollard TD: Effects of cytochalasin, phalloidin, and pH on the elongation of actin filaments. Biochemistry 1991, 30:1973-1980.

49. Lambeth JD: NOX enzymes and the biology of reactive oxygen. Nat Rev Immunol 2004, 4:181-189.

50. Li Q, Zhang Y, Marden JJ, Banfi B, Engelhardt JF: Endosomal NADPH oxidase regulates $\mathrm{C}$-Src activation following hypoxia/reoxygenation injury. Biochem J 2008, 411:531-541.

51. Ushio-Fukai M: Localizing NADPH oxidase-derived ROS. Sci STKE 2006, 2006:re8.

52. Morishige T, Yoshioka Y, Tanabe A, Yao X, Tsunoda S, Tsutsumi Y, Mukai Y, Okada N, Nakagawa S: Titanium dioxide induces different levels of IL1 beta production dependent on its particle characteristics through caspase-1 activation mediated by reactive oxygen species and cathepsin B. Biochem Biophys Res Commun 2010, 392:160-165.

53. Fubini $B$, Hubbard A: Reactive oxygen species (ROS) and reactive nitrogen species (RNS) generation by silica in inflammation and fibrosis. Free Radic Biol Med 2003, 34:1507-1516.

54. Meyer JW, Schmitt ME: A central role for the endothelial NADPH oxidase in atherosclerosis. FEBS Lett 2000, 472:1-4.

55. Kawahara T, Kuwano Y, Teshima-Kondo S, Kawai T, Nikawa T, Kishi K Rokutan K: Toll-like receptor 4 regulates gastric pit cell responses to Helicobacter pylori infection. J Med Invest 2001, 48:190-197.

56. Schins RP: Mechanisms of genotoxicity of particles and fibers. Inhal Toxicol 2002, 14:57-78.
57. Kagan VE, Tyurina YY, Tyurin VA, Konduru NV, Potapovich Al, Osipov AN, Kisin ER, Schwegler-Berry D, Mercer R, Castranova V, Shvedova AA: Direct and indirect effects of single walled carbon nanotubes on RAW 264.7 macrophages: role of iron. Toxicol Lett 2006, 165:88-100.

58. Oberdorster G, Geleinr R, Johnston C, Mercer P, Corson N, Finkelstein J: Ambient ultra fine particles: Inducers of acute Lung injury? Relationships between respiratory disease and exposure to air pollution. ILSI Press, Washington, DC; 1998, 216-229.

59. Terry $L$, Shows EB, Wente SR: Crossing the nuclear envelope: hierarchical regulation of nucleocytoplasmic transport. Science 2007, 318:1412-1416.

60. Chen M, von Mikecz A: Formation of nucleoplasmic protein aggregates impairs nuclear function in response to $\mathrm{SiO} 2$ nanoparticles. Exp Cell Res 2005, 305:51-62.

61. Lison D, Thomassen LC, Rabolli V, Gonzalez L, Napierska D, Seo JW, KirschVolders M, Hoet P, Kirschhock CE, Martens JA: Nominal and effective dosimetry of silica nanoparticles in cytotoxicity assays. Toxicol Sci 2008, 104:155-162.

62. Waters KM, Masiello LM, Zangar RC, Tarasevich BJ, Karin NJ, Quesenberry RD, Bandyopadhyay S, Teeguarden JG, Pounds JG, Thrall BD: Macrophage responses to silica nanoparticles are highly conserved across particle sizes. Toxicol Sci 2009, 107:553-569.

63. Barnes CA, Elsaesser A, Arkusz J, Smok A, Palus J, Lesniak A, Salvati A, Hanrahan JP, Jong WH, Dziubaltowska E, et al: Reproducible comet assay of amorphous silica nanoparticles detects no genotoxicity. Nano Lett 2008, 8:3069-3074.

64. Inui S, Lee YF, Haake AR, Goldsmith LA, Chang C: Induction of TR4 orphan receptor by retinoic acid in human $\mathrm{HaCaT}$ keratinocytes. J Invest Dermatol 1999, 112:426-431.

doi:10.1186/1743-8977-8-1

Cite this article as: Nabeshi et al: Amorphous nanosilica induce endocytosis-dependent ROS generation and DNA damage in human keratinocytes. Particle and Fibre Toxicology 2011 8:1.

\section{Submit your next manuscript to BioMed Central and take full advantage of:}

- Convenient online submission

- Thorough peer review

- No space constraints or color figure charges

- Immediate publication on acceptance

- Inclusion in PubMed, CAS, Scopus and Google Scholar

- Research which is freely available for redistribution

Submit your manuscript at www.biomedcentral.com/submit
C Biomed Central 